\title{
Research on Evaluation of Working Capital Management Efficiency of Electric Power Listed Companies
}

\author{
Hong Liu ${ }^{1}$, Ji Xuan Pan $^{2 *}$, Han Qing Yuan ${ }^{1}$, Hui Ling Li ${ }^{1}$, Jing Wang ${ }^{1}$, Jia Jun Wang ${ }^{1}$ and Xiao Hua Song ${ }^{2}$ \\ ${ }^{1}$ STATE GRID HEBEI INFORMATION \& TELECOMMMUNICATION BRANCH, No.10 Fuqiang street, Yuhua District, Shijiazhuang \\ City, Hebei Province, China \\ ${ }^{2}$ North China Electric Power University, No. 2 Beinong Road, Changping District, Beijing, Chian
}

\begin{abstract}
Power companies are mainly capital-intensive companies, and the efficiency of working capital management has a profound impact on the sustainability and stability of the development of power companies. This paper uses the DEA-CCR method to measure the working capital management efficiency of listed Chinese power companies from 2014 to 2019, and uses the Tobit regression method to analyze the factors that affect the working capital management efficiency. The results show: (1) The overall efficiency of working capital management of listed Chinese power companies is low, and there is still much room for improvement. (2) Decomposition of comprehensive technical efficiency results in pure technical efficiency and scale efficiency, both of which have an important impact on the overall working capital management efficiency of listed Chinese power companies. (3) Among listed electric power companies, the overall working capital management efficiency of central enterprises is lower than that of non-central enterprises. In response to the above conclusions, this article proposes measures such as reforming the working capital management system, optimizing the profitability of core businesses, and improving supply chain capital management to improve the working capital management efficiency of listed electric power companies.
\end{abstract}

\section{Introduction}

Working capital management is a key part of financial management. The profitability of an enterprise in a certain period depends on the efficiency of its working capital management. Therefore, working capital management has become the focus of modern business development. Today's enterprises focus on the two core links of operation and investment. Electricity listed companies are capital-intensive companies with a huge amount of working capital, so good working capital management is particularly important for electric power companies. To analyze the current status of working capital management efficiency of listed electric power companies, this paper uses DEA analysis method to select typical power companies to measure working capital management efficiency.And this paper uses Tobit model to analyze the influencing factors.

\section{Literature review}

At present, domestic and foreign researches on corporate working capital management mainly focus on two aspects: working capital management concept innovation and operational management efficiency.

Ratnam Vijayakumaran analysis found that the company's profitability and working capital have a nonlinear inverted U-shaped relationship, and there is an optimal working capital management level[1].Ding Wei emphasized that the capital management of enterprises should pay attention to the overall awareness, learn from the experience of developed countries, and treat the entire group as a whole to do a unified financial management plan[2]. Cheng Xin sheng believes that companies should establish supply chain alliances and carry out in-depth cooperation in various ways, which is conducive to improving the efficiency of working capital management[3]. Lei Zhen hua studied the management of corporate working capital from the perspective of symbiosis[4]. The management of capital cannot only rely on itself, but must rely on the existence of its stakeholders. Wang Zhen jie pointed out that in the process of fund management by non-financial companies, capital management should not be over-applied. The use of excessive financial leverage may increase corporate risks[5].In terms of working capital management efficiency. Lingesiya Kengatharan considers the nature of working capital itself and believes that working capital management efficiency is closely related to corporate governance practices[6].

Most of the above-mentioned documents stay on theoretical analysis and correlation analysis, and rarely involve the company's direct quantitative efficiency evaluation, which is also the innovation of this article. In this paper, the DEA-CCR model is used to construct a complete input-output indicator system to measure the working capital management efficiency of listed electric 
power companies, and combined with the Tobit model analysis results it puts forward targeted suggestions to improve working capital management efficiency and improve company operations.

\section{Description of DEA model and index selection}

\subsection{DEA-CCR model selection}

A. Charnel and WW Cooper proposed the data envelopment analysis method (DEA). The advantage of this method is that it can solve multiple input and output problems, and does not require the production function correspondence between different input and output indicators, and can compare Multiple decision-making units are effectively evaluated, and the efficiency value of each decision-making unit is obtained. The DEA model has undergone years of evolutionary research. The most typical one is the CCR model. The CCR model can decompose the efficiency calculation results to obtain pure technical efficiency and scale efficiency, which reflect the technical level of the financial management of power enterprises and the efficiency of business scale for working capital management. Impact. Therefore, in order to obtain more accurate measurement results and analyze the direction of improving the efficiency of working capital management of power companies, this paper chooses the DEA-CCR model to measure the efficiency of working capital management.

\subsection{Description of index selection}

This paper selects 12 listed power companies, which are Bao xin Energy, Yangtze Power, Da tang Power, Fu ling Power, Guodian Power, Hua neng Power International, Ming xing Power, Ping gao Electric, Shenzhen Energy, Xi chang Power, China General Nuclear Power and China Nuclear Power. The above companies are selected for the following two reasons: 1 . The above companies are large in scale and have strong representativeness, which can fully reflect the efficiency of working capital management

Table 2 . Working capital management efficiency pure technical efficiency and scale efficiency table

\begin{tabular}{|c|c|c|c|c|c|c|c|c|c|c|c|c|c|c|c|c|c|c|}
\hline Company & \multicolumn{3}{|c|}{$\mathbf{2 0 1 4}$} & \multicolumn{3}{|c|}{$\mathbf{2 0 1 5}$} & \multicolumn{3}{c|}{$\mathbf{2 0 1 6}$} & \multicolumn{3}{c|}{$\mathbf{2 0 1 7}$} & \multicolumn{3}{c|}{$\mathbf{2 0 1 8}$} & \multicolumn{3}{c|}{2019} \\
\hline Bao xin Energy & 1.00 & 1.00 & 1.00 & 0.83 & 1.00 & 0.83 & 1.00 & 1.00 & 1.00 & 1.00 & 1.00 & 1.00 & 1.00 & 1.00 & 1.00 & 0.81 & 1.00 & 0.81 \\
\hline Yangtze Power & 1.00 & 1.00 & 1.00 & 1.00 & 1.00 & 1.00 & 1.00 & 1.00 & 1.00 & 0.85 & 1.00 & 0.85 & 1.00 & 1.00 & 1.00 & 1.00 & 1.00 & 1.00 \\
\hline Da tang Power & 0.17 & 0.17 & 1.00 & 0.13 & 0.13 & 0.97 & 0.02 & 0.02 & 0.81 & 0.72 & 0.87 & 0.83 & 0.34 & 0.37 & 0.92 & 0.68 & 0.68 & 1.00 \\
\hline Fu ling Power & 1.00 & 1.00 & 1.00 & 1.00 & 1.00 & 1.00 & 0.62 & 0.69 & 0.91 & 0.74 & 0.74 & 0.99 & 0.90 & 1.00 & 0.90 & 1.00 & 1.00 & 1.00 \\
\hline Guo dian Power & 0.54 & 1.00 & 0.54 & 0.05 & 0.08 & 0.69 & 1.00 & 1.00 & 1.00 & 1.00 & 1.00 & 1.00 & 1.00 & 1.00 & 1.00 & 0.97 & 0.97 & 1.00 \\
\hline Hua neng International & 0.14 & 0.46 & 0.31 & 0.09 & 0.10 & 0.98 & 1.00 & 1.00 & 1.00 & 0.35 & 0.37 & 0.95 & 0.22 & 0.27 & 0.82 & 0.19 & 0.19 & 1.00 \\
\hline Star power & 1.00 & 1.00 & 1.00 & 0.62 & 0.76 & 0.82 & 1.00 & 1.00 & 1.00 & 1.00 & 1.00 & 1.00 & 1.00 & 1.00 & 1.00 & 1.00 & 1.00 & 1.00 \\
\hline Ping gao Electric & 0.84 & 1.00 & 0.84 & 1.00 & 1.00 & 1.00 & 0.29 & 0.82 & 0.36 & 0.51 & 1.00 & 0.51 & 0.28 & 1.00 & 0.28 & 0.41 & 0.41 & 1.00 \\
\hline
\end{tabular}

in the power industry. 2. The financial data of listed companies in the electric power industry are publicly announced to facilitate the acquisition of sufficient and accurate public data. The financial data used for measurement in this article are all from the 2014-2019 financial annual reports of listed companies.

For the measurement of working capital management efficiency of listed companies in the power industry, the focus is on measuring the output effect of their capital investment. Under this ideological guidance, the investment indicators select cash outflows from operating activities and cash outflows from investment activities, because the normal operation and profitability of enterprises mainly come from operating activities and investment activities. Corresponding output indicators select core profit rate, cash cycle, working capital ratio and foreign investment income. The first two output indicators correspond to cash outflows from operating activities and can fully reflect the profitability and turnover capacity of operating cash. Investment income corresponds to the cash outflow of investment activities, which measures the level of investment income generated by investment activities. The specific input-output indicators selected are shown in Table 1.

Table 1. Description of selection of input-output indicators

\begin{tabular}{|c|c|}
\hline $\begin{array}{l}\text { Input-output } \\
\text { project }\end{array}$ & Specific indicators \\
\hline \multirow{2}{*}{ Capital investment } & $\begin{array}{c}\text { Cash outflow from operating } \\
\text { activities }\end{array}$ \\
\hline & $\begin{array}{c}\text { Cash outflow from investing } \\
\text { activities }\end{array}$ \\
\hline \multirow[t]{3}{*}{ Output effect } & $\begin{array}{c}\text { Core profit margin }=\text { core profit } / \\
\text { operating income Core profit }= \\
\text { operating income-operating costs- } \\
\text { taxes and surcharges-sales expenses- } \\
\text { administrative expenses-financial } \\
\text { expenses }\end{array}$ \\
\hline & Working capital ratio \\
\hline & Investment income \\
\hline
\end{tabular}

\subsection{DEA efficiency measurement}




\begin{tabular}{|c|c|c|c|c|c|c|c|c|c|c|c|c|c|c|c|c|c|c|}
\hline Shenzhen Energy & 0.42 & 0.42 & 1.00 & 0.38 & 0.39 & 0.97 & 0.83 & 0.83 & 1.00 & 0.17 & 0.17 & 0.99 & 0.13 & 0.14 & 0.98 & 1.00 & 1.00 & 1.00 \\
\hline $\mathrm{Xi}$ chang Power & 1.00 & 1.00 & 1.00 & 1.00 & 1.00 & 1.00 & 1.00 & 1.00 & 1.00 & 1.00 & 1.00 & 1.00 & 1.00 & 1.00 & 1.00 & 0.08 & 0.10 & 0.80 \\
\hline $\mathrm{CGN}$ & 0.58 & 1.00 & 0.58 & 0.29 & 0.49 & 0.59 & 1.00 & 1.00 & 1.00 & 1.00 & 1.00 & 1.00 & 0.42 & 1.00 & 0.42 & 0.23 & 0.79 & 0.29 \\
\hline China Nuclear Power & 0.16 & 0.24 & 0.68 & 0.18 & 0.29 & 0.61 & 0.19 & 0.19 & 0.98 & 0.14 & 0.94 & 0.15 & 0.14 & 0.66 & 0.21 & 0.11 & 0.48 & 0.23 \\
\hline
\end{tabular}

The first column in Table 2 is the efficiency of working capital management, the second column is the pure technical efficiency obtained by decomposition, and the third column is the scale efficiency. As shown in Table 2, among the 12 power companies that have achieved the best efficiency by 2019, only four power companies, Yangtze Power, Fu ling Power, Star Power, and Shenzhen Energy, are the remaining power companies. It can be seen that most of the listed power companies are in the low efficiency range in terms of working capital management, and there is great potential for improvement. The average working capital management efficiency of the 12 power companies from 2014 to 2019 was $0.65,0.55,0.75,0.71$, $0.62,0.62$, and the overall trend was an increase first and then a decrease. The efficiency change is caused by the combined effect of pure technical factors and scale factors. The insufficiency of pure technical factors indicates that some power companies have a lot of room for improvement in budget management and the construction of working capital management systems and systems, and need to improve their financial management capabilities; insufficient scale factors indicate that some power companies need to adjust their business scales The current working capital scale is controlled within a reasonable range to maximize the efficiency of capital units.

From the perspective of the nature of enterprises, central enterprises account for less than half of the total number of enterprises with the best overall technical efficiency. The optimal proportion of comprehensive technical efficiency of central enterprises is significantly smaller than that of other state-owned enterprises. On the whole, the overall working capital management efficiency of power companies is not high, but the working capital management efficiency of non-central enterprises is significantly higher than that of central enterprises. However, among the central enterprises, there are also enterprises like Yangtze Power that have been in the best efficiency for most years. It is understood that Yangtze Power has a late registration and establishment, a clear fund management structure, and a financial sharing center and financial informatization level that are at the forefront of central enterprises. The advanced organizational

Table 4. Regression results of factors affecting working capital management efficiency of listed electric power companies structure and excellent core business profitability guarantee that its working capital management level is higher than other central enterprises.

\section{Analysis of influencing factors}

\subsection{Tobit model influencing factors}

The above application of DEA-CCR model estimates that the efficiency of working capital management is affected by two indicators of enterprise scale and pure technical efficiency factors. Therefore, when selecting the indicator direction, the corresponding specific indicators are also selected from these two perspectives. Working capital management The selection of factors affecting efficiency is shown in Table 3:

Table 3 . Description of factors affecting working capital management efficiency

\begin{tabular}{|c|c|}
\hline Influencing factors & Measurement standard \\
\hline Enterprise size & Total assets \\
\hline Assets and liabilities & Total liabilities/total assets \\
\hline Operating profit margin & $\begin{array}{c}\text { Operating profit ratio }= \\
\text { operating profit / total } \\
\text { business income } \times 100 \%\end{array}$ \\
\hline $\begin{array}{c}\text { Main business income } \\
\text { growth rate }\end{array}$ & $\begin{array}{c}\text { Main business income } \\
\text { main business income-last } \\
\text { period's main business } \\
\text { income } / \text { last period's main } \\
\text { business income * 100\% }\end{array}$ \\
\hline
\end{tabular}

\subsection{Tobit Empirical Analysis}

This paper uses quantitative analysis software to conduct a Tobit quantitative regression analysis on the working capital management efficiency of 12 companies. The analysis results of the correlation coefficient of each explanatory variable are shown in the table:

\begin{tabular}{|c|c|c|c|c|c|c|}
\hline factors & $\mathbf{2 0 1 4}$ & $\mathbf{2 0 1 5}$ & $\mathbf{2 0 1 6}$ & $\mathbf{2 0 1 7}$ & $\mathbf{2 0 1 8}$ & $\mathbf{2 0 1 9}$ \\
\hline Enterprise size & $\begin{array}{c}-1.00 \mathrm{E}- \\
08\end{array}$ & $\begin{array}{c}-1.00 \mathrm{E}- \\
08\end{array}$ & $\begin{array}{c}-5.00 \mathrm{E}- \\
09\end{array}$ & $\begin{array}{c}-1.00 \mathrm{E}- \\
08\end{array}$ & $\begin{array}{c}-4.00 \mathrm{E}- \\
09\end{array}$ & $\begin{array}{c}-8.40 \mathrm{E}- \\
09\end{array}$ \\
\hline $\begin{array}{c}\text { Asset-liability } \\
\text { ratio }\end{array}$ & - & - & - & - & - & -0.03 \\
\hline $\begin{array}{c}\text { Operating profit } \\
\text { margin }\end{array}$ & 0.426997 & 0.211764 & 2.31604 & 0.328689 & 0.486785 & 1.002693 \\
\hline $\begin{array}{c}\text { Main business } \\
\text { income growth } \\
\text { rate }\end{array}$ & 0.180648 & 0.189512 & - & - & - & 0.575873 \\
\hline \multicolumn{2}{|c|}{0.608469} & 0.019703 & 0.68 \\
\hline
\end{tabular}


It can be seen from Table 4 that from 2014 to 2019, the enterprise scale, asset-liability ratio and working capital management efficiency of 12 listed electric power companies showed a negative correlation. The growth rate of operating income was also negatively correlated in most years, but in 2019 It also has a relatively strong positive correlation. Operating profit margin and working capital management efficiency show a positive correlation. The specific analysis is as follows:

(1) Enterprise scale: From 2014 to 2019, the enterprise scale and working capital management efficiency showed a negative correlation, but the impact was small. It can be seen that the enterprise scale and capital scale of today's listed electric power companies are already very large, and further increase in investment has been difficult to produce scale benefits.

(2) Asset-liability ratio: From 2014 to 2019, there is an obvious negative relationship between the corporate assetliability ratio and the efficiency of working capital management. The debt-to-asset ratio reflects the solvency of an enterprise and is an important aspect of the level of enterprise financial management. The debt-to-asset ratio is the proportion of corporate liabilities to assets, and its suitable size is generally between $40 \%-60 \%$. From the regression results, it can be seen that the high debt-to-asset ratio of power companies affects the efficiency of their corporate working capital management.

(3) Operating profit margin: From 2014 to 2019, the operating profit margin has always been positively correlated with the efficiency of working capital management, and the correlation is very obvious. Operating profit margin reflects the operating efficiency of an enterprise, reflects the true profitability of an enterprise, and is a key indicator reflecting the profitability of an enterprise.

(4) Main business revenue growth rate: From 2014 to 2019, the revenue growth rate and working capital management efficiency mostly showed a negative correlation, with a moderate degree of correlation. The main business income growth rate reflects the company's development capability index, which can reflect the future development trend and development capability of the company's main business. The early expansion has saturated the traditional power generation side, and the expansion of the main business has brought about a decline in the efficiency of fund management. With the promotion of a variety of new energy and new forms of power generation, the expansion of the main business and the efficiency of fund management have become positively correlated.

\section{Conclusions and suggestions}

According to the above research, when analyzing the working capital management efficiency of listed electric power companies in China, this article measures the working capital management efficiency of 12 listed electric power companies in China from 2014 to 2019 based on the DEA model and the Tobit model and analyzes its impact mechanism. Conclusions are drawn as follows :

(1) The working capital management efficiency of
China's listed power companies is still at a relatively low level, while the gap in working capital management efficiency between central-owned and non-central-owned power generation companies is relatively obvious. After decomposing working capital management efficiency into pure technical efficiency and scale efficiency, it can be concluded that both of them play an important role in improving working capital management efficiency and are both key reform drivers and improvement directions.

(2) Through the Tobit analysis, it can be concluded that the current power companies can optimize the efficiency of working capital management in several specific aspects: optimizing the scale of the company, adjusting the debt ratio of the power company, and improving the profitability. Select and analyze financial indicators as a means to optimize business management and improve working capital management efficiency from the two aspects of pure technical factors and scale factors in enterprise development.

In response to the above research results, the following suggestions are made:

(1) Optimize and adjust the enterprise scale. Electric power companies are capital-intensive companies, and the huge demand for funds objectively determines the largescale characteristics of power companies. At present, power companies should appropriately reduce their scale, reduce non-essential industrial investment, and optimize the direction of capital investment. Optimize and reorganize businesses that are not profitable and risky, and reduce business if necessary.

(2) Adjust the debt ratio of power enterprises. Power companies need a lot of financial support from initial construction to future development. At the same time, they will bring a heavy financial burden to the company. Appropriate reduction of the asset-liability ratio has become a key measure. Power companies appropriately slow down the pace of investment, and prudently choose the objects that need investment under the premise of considering market potential; companies promote multichannel financing, appropriately expand the proportion of equity financing, and share private capital dividends.

(3) Take multiple measures to improve profitability. Power companies should make strategic adjustments to the corporate power generation structure, develop energy in accordance with local conditions, selectively promote the construction of cogeneration projects with leading economic benefits, and research and develop new energy power; correctly channel the government, power grids, power generation companies, and supply chain companies The government has improved the coal-electricity linkage mechanism.

(4) Improve the budget management system. Electric power companies are typical capital-intensive companies, and they need scientific planning and rational use of modern capital management techniques during their business development. Do a good job in the advance planning of corporate funds, formulate scientific monthly, quarterly, and annual funding budgets, and optimize the fine management level of power companies' working capital. 


\section{References}

1. Ratnam Vijayakumaran.Efficiency of Working Capital Management and Firm Value: Evidence From Chinese Listed Firms[J].International Journal of Financial Research,2019,10(6).

2. Ding Wei. Unified management of group company working capital. Modern Business. 2018: 13

3. Cheng Xinsheng; Hou Yucheng. Research on optimization of RS company based on supply chain working capital management. Friends of Accounting. 2019: 71-78

4. Lei Zhenhua; Zhang Yujie; Xiao Mengdi. Discussion on the working capital management of manufacturing enterprises from the perspective of symbiosis. Finance and Accounting Communications. 2019: 7578

5. Wang Zhenjie; Wang Hui. The uncertainty of economic policy, the range of strategic changes and the excessive capital management of enterprises. Modern Finance (Journal of Tianjin University of Finance and Economics). 2019: 22-36

6. Lingesiya Kengatharan;W. S. Sanoli Tissera.Do Corporate Governance Practices Influence Working Capital Management Efficiency? Evidence From Listed Manufacturing Companies in Sri Lanka[J]. Research in World Economy,2019,10(3). 